\title{
Traditional Game Tools to Support Democratic Values
}

\author{
Sri Hilmi Pujihartati ${ }^{1}$, and Mahendra Wijaya ${ }^{2}$ \\ ${ }^{I}$ Department of Sociology, Faculty of Social and Political Sciences, Universitas Sebelas Maret, Jl. Ir. Sutami 36 A, \\ Surakarta, Indonesia \\ \{srihilmipujiastuti\}@yahoo.co.id
}

Keywords: Democracy, commonness, systematic

\begin{abstract}
Democracy becomes a central issue in the last decade related to social change dynamics and Indonesian state administration. Indonesians highly expect the improvement of democratic development results in their state. On the other hand, there are some debates on substance and implementation of democracy. Democratic values understood by most people instead show pseudo-democracy or even are very different from the expected ones. Hayness (2000) represents that in most third world countries, democracy reveals more formality aspect, concentrated on procedure and institutional order, and particularly focusing on the general election. Democracy needs not only law, regulation and institution that can enforce it, but also a democratic attitude. Thus, democratic value inculcation is something very important to implement earlier, systematically, in a planned and sustainable manner in order not to lead to anarchism. The traditional game is an attempt of inculcating democratic value, as in playing traditional game there are freedom, equality, cooperation, competition, and confidence. To support the children to play, playing vehicles or tools are needed such as Dakon for playing Dakon, Gasing for playing Gasing, rubber bracelet for playing rope jump and etc. Thus, traditional game tools industry is a means supporting the growth of democratic values apparently.
\end{abstract}

\section{INTRODUCTION}

Democracy is no longer strange in the people's ears. So is it in Indonesia that has applied democratic system since its early independence period until today. Huntington in Fukuyama (2015) mentions that the third wave of democratization occurred after the collapse of Berlin walls and just before the breakdown of Soviet Union. East Europe moved fast far away from communism. Authoritarianism has degraded just like the case occurring in Egypt and became anarchy in Libya, Yemen, and also Syria along with seeing the emergence of new radical movement, Islamic State in Iraq and Syria (ISIS).

On the other hand, there are some debates on substance and implementation of democracy. The result of a survey conducted by Sharma, et al. (2010) found that considering Indonesian people's democratic conception, $38 \%$ of people negotiate independently, $41 \%$ do know not it and $4 \%$ call it harmony, $2 \%$ talk about individual's opportunity, and $2 \%$ of power is on the people's hand. Those stating not knowing democracy largely come from junior high school or below. There are some arguments about democracy in Indonesia: $74 \%$ believe in Indonesia as a democratic value, $15 \%$ state Indonesia has two sides: democratic and nondemocratic, $6 \%$ state that Indonesia is not democratic and $5 \%$ state that they do not know it. About $72 \%$ of Indonesian people state that they love democracy, $20 \%$ state that type of government does not matter to them, $4 \%$ state that non-democratic government sometimes is better, and $4 \%$ states that they do not know it. It indicates that most people have a big expectation to democracy.

To realize democracy, people should master concept and values contained in democracy as democratic life attitude or ideology. In relation to people's conception, an effective attempt is required to deliver the purpose of concept existing in democratic values. And the realization through the learning process can be accomplished through democratic education. Democratic education is essential to socialize democratic value in order to be acceptable and implementable to citizens. 
Democratic education is essentially intended to result in the democratic value in the framework of realizing an ideal democratic order. Democracy is not only from people, by people, and for people, or people's direct participation in political decision making, but also more than that.

Hayness (2006) democracy basically has 2 meanings: 1) Democracy is a form of government; it is consistent with the word democracy itself (demos: people; cratein: governs) so that literally democracy means people govern. 2) Democracy is a life value or ideology. Democracy as a value not only relates to interest affair but also can be practiced in daily life in family, school and society. Democracy in most third world countries, according to him, is a formal one. Hayness (2000) represents that in most third world states, democracy reveals more formality aspect, concentrated on procedure and institutional order, and particularly focusing on the general election. In line with Hayness, Dewy (1976) argues that democracy is not only political institution and representative procedure matters but also should actually create life way, written moral ideals in daily life.

In the attempt of developing democratic life, a traditional game has an opportunity of accustoming children to practicing democratic life. It is because a traditional game contains an awareness of diversity including cultural diversity based on the difference with other people thereby growing an understanding on commonness value (Rettig, 1995).

Indonesian people are the manifestation of a nation's diversity existing in the world. Therefore, Indonesian character should be inculcated earlier. Indonesian character in this context can be defined as Indonesian human character distinguishing them from other human beings as the manifestation of self-existence, and self-image of Indonesians. Suryana (2015) suggests that base of Indonesian character is nationalism spirit and love for homeland values.

Spirit of nationalism is a way of thinking, acting, and having insight putting the nation and state's interest in self- and group-interest. Meanwhile, loveto-homeland value is a way of thinking, having a stance, and acting indicating loyalty, care and high appreciation to the nation and its, physical, social, economic, cultural and political environments.

Mishbach (2006) suggests that in fact, the meaning of traditional game values contain moral messages with a noble local wisdom content, but regretfully, the present generation care less about it due to limited reading source or practical method to teach values raised from nation ethnic diversity vocabularies in Indonesia. Despite different language and separate geographic location, in fact the ideology of most ethnics in Indonesia prioritizes mutual cooperation (gotong royong), tolerance, and solidarity values. Lickona T (1991) in a study on children development conducted by University of Otago's team in Dunedin, New Zealand since 1987 in long term followed by 1000 children into adulthood shows that since the age of 3 years, a child predictably has what predisposition in his/her adulthood later. Clark \& Milner say that since the age of 4 years old, a child has been able to express a discriminative attitude to different people.

Similarly, through playing, children can socialize, interact with but not fuse into others and still hold on their own identity. It becomes children's habit thereby making them accustomed with and same anywhere they are.

Huitt, W (2004) suggests that value is an abstract reality, and exists in human life. Abstract value cannot be sensed, the observable thing is only the valued object. Esthetic value is subjective in nature. An individual will feel happy seeing a painting he/she considers as very beautiful, but others perhaps do not like the painting. We cannot compel an argument that the painting is beautiful. Moral value is a part of a value, that defined the good and bad behavior. A moral is always related to value, but not all values are moral ones. Moral relates to human behavior. It is this moral value that is related to our daily behavior.

Ghost P (2015) suggests that playing requires physical and mental health, but in addition, a traditional game could also enhance a group's identity and strengthen kinship bond.

Misbach (2006) reveals that a nation's national resilience is not merely oriented to the nation's ability to defend its nation physically, but also seen from an assessment of how the nation maintains and develops its original cultural values. Those values should be maintained and developed to reinforce the nation's identity.

For that reason, traditional games can be utilized to be an attempt at realizing democratic culture and something that should be activated and socialized to children. Traditional games will keep running when it is supported by some tools to play it.

\section{METHODS}

This study employed a descriptive qualitative approach aiming to describe the production of 
traditional game tools as the manifestation of support for the growth of democratic value. It is because traditional games are inseparable from playing infrastructures such as playground and tools used to play the game. Traditional games such as rope jump, Gasing, Bakiak, and Egrang need tools. In socializing traditional games, we invited Anak Bawang community as the one actively socializing traditional game.

This research was taken place in Kelurahan Jebres of Surakarta Municipal because Kelurahan Jebres is the one stipulated to be a children-friendly village. As a children-friendly village, some activities existing in Kelurahan Jebres are emphasized on those children-oriented. Moreover, in this Kelurahan there are park facilities used to accommodate the people's activity including children's. The park provided in Kelurahan Jebres is located in RW 20 and RW 23 called Taman Tempuran in RW 20 and Taman Sawah Karang in RW 23.

Techniques of collecting data used in this research were observation, in-depth interview, documentation, and FGD. Focus Group Discussion presented selected informants consisting of Kelurahan Apparatus including Lurah Jebres (Village Head) and Kelurahan apparatus, representative society including public figure, Family Welfare Empowerment Activator Team, Karang Taruna (Youth Organization) and administrator of Forum Anak Surakarta, and producers of traditional game tools supporting the traditional games.

Data validation was carried out using triangulation; triangulation used in this study was source triangulation; source triangulation was intended to get higher reliability by means of comparing and rechecking an information's reliability obtained through different sources. It could be done by means of: 1) comparing what is said before the public and what is done personally; 2) comparing the data resulting from observation and the data resulting from the interview; and 3) comparing the result of the interview and the content of related document. Such triangulation is expected to improve the validity of research result.

The technique of analyzing data used was an interactive model of analysis consisting of 3 components: data reduction, data display, and conclusion drawing (Sutopo, 2002: 91-96).

\section{RESULTS AND DISCUSSION}

Richard (2004) says that democracy is a life order characterized by liberty, equality, and fraternity characteristics. Democracy is a set of ideas and principles about independence in commonness occurring in fraternity situation. In relation to the traditional game, traditional games serve to cultivate commonness and to cultivate freedom or independence, as explained below.

\subsection{Traditional Game serves to cultivate commonness}

A game can be useful in cultivating commonness, as suggested by Michaela et al (2014), that game used during learning in the classroom is useful in students' active learning, helps them establish teamwork, and improve their self-esteem. A student will repeat the experience by playing the game because there is something he/she has never done previously and they will keep repeatedly play the game so that they can solve the problem more quickly and have more self-confidence. Therefore, in playing a traditional game, there is equality between one and another thereby commonness grows, and this principle is in line with the democratic principle.

In this study, people in Kelurahan Jebres have often held preexisting activities in Taman Sawah Karang and Taman Tempuran (Sawah Karang and Tempuran Parks) by means of assembling while enjoying the parks developed by Surakarta Municipal government. These parks are located in the edge of Bengawan Solo River originally aiming to protect the river bank area they usually use for disposing of unused goods. After their establishment in 2015, people use these parks widely to enjoy the parks' beauty.

In the activity of activating traditional games in a community, we also used Taman Sawah Karang and Taman Tempuran. Children seemed to play the game enthusiastically and listen to various fairy tales we present. People of Kelurahan Jebres welcomed our team's arrival very friendly, and even they supported this activity by providing any snacks and they have prepared for welcoming our arrival long before. In this activity, members of PKK (Family Welfare Empowerment) program contributed to this activity organization. They helped in inviting children, providing snack, and involving community leaders to attend the socialization activity we held. In this activity, we also established a community aiming to activate traditional games and socialize it 
to the community, and we introduce to the people that Kelurahan Jebres has had a community responsible directly for the sustainability of traditional games.

In this activity we gave aids in the form of traditional game tools as the stimulus to socialize traditional games. Thus, children will recognize and practice them in daily life not only when it is socialization. For that reason, we give stimulant fund in order to make this traditional game socialization activity running sustainably through the establishment of community responsibility. For the fund we have given, we will ask the community for accountability when we make monitoring visit sometime. It is intended to make traditional games promoted continuously in the field. They seem to welcome our expectation, as indicated by the presence of lurah (village head) and some chairpersons of local neighborhoods (RT and RW) during the socialization process. In fact, the presence of lurah and PKK activators impacted on the local people's enthusiasm, as can be seen from the presence of children as well as their parents during the socialization process.

\subsection{Traditional Game serves to cultivate freedom}

Democratic principle contains freedom, the freedom in commonness occurring in fraternity situation. Every individual has freedom and is entitled to use his/her freedom. Nevertheless, it does not mean that freedom is allowed to oppress other as others also have the freedom to be appreciated. Therefore, the important character contained in democratic life is the recognition of equality for all differences existing, including sex difference.

Traditional games do not discriminate male and female, for example, in playing Gobak Sodor male and female play equally without any condition to be fulfilled by either male or female, the taller or the shorter, regardless race, religion, and language, everyone plays together and tries to socialize with his or her playmates.

\section{CONCLUSIONS}

Basically, democracy needs not only law, regulation, and an institution that can enforce it. Many states instead perform pseudo-democracy because democracy is concentrated on general election process only. Thus, democratic values should be inculcated earlier since childhood, as it can be used later as daily life ideology and attitude.

Essentially traditional games inculcate many democratic principles based on life order characterized by freedom, equality, and fraternity characteristics.

\section{REFERENCES}

Hayness, Jeff, 2000. Demokrasi dan Masyarakat Sipil di Dunia Keiga: Gerakan Politik Baru kaum Terpinggirkan, diterjemahkan dari judul asli "Democracy and Civil Society in The World politics and New political Movement " oleh P Soemitro, Yayasan Obor Indonesia, Jakarta.

Sharma, Rakesh Laure Serpe and Asri Suryandari (2010), Indonesia Electoral survey 2010 November 2010, IFES 9International Foundation for Electoral system) for the Auatralian Agency for International Development.

Hayness, Jeff. 2006. Democracy and Political Change in The Third World. Taylor And Francis. London

Rettig, Michel. 1995. Play and Cultural Diversity. the journal of educational issue of Language Minoryty students, V.15, winter 1995 Boise State University.

Suryana, Yaya \& Rusdian, H.A. (2015). Pendidikan Multikultural. Bandung: CV Pustaka Setia.

Ghosh, P (2015) Traditional Sports and Games Culture Around West Bengal. International Journal of novel Research in Humanity And Social Sciences Vol 2 Issue 3 pp:1-5, Month May-June 2015

Misbach, Ifa H (2006) Peran Permainan Tradisional Yang Bermuatan Edukatif Dalam Menyumbang Pembentukan Karakter dan Identitas Bangsa. Laporan Penelitian UPI Bandung. diundu tanggal 3 Agustus 2017.

Citation: Huitt, W. (2004). Values. Educational Psychology Interactive. Valdosta, GA: Valdosta State University. Retrieved [date], from http://www.edpsycinteractive.org/topics/affect/values. $\underline{\mathrm{html}}$

Fukuyama, Francis (2015).Why Is Democracy Performing so Porly. Journal Of Democracy, Volume 26 Number 1 Januari 2015.

Lickona, T. (1991) What is Effective Character Education ? $\quad$ from http://www.mtsm.org/pdf/what $\% 20$ is $\% 20$ effective $\% 2$ 0character\%20education.pdf

Dewey J (1976 [1939]) Creative democracy: The task before us. In: Boydston J (ed.) John Dewey: The Later Works, 1925-1953, Vol. 14. Carbondale: Southern Illinois University Press, pp. 224-230. Available at: http://chipbruce.files.wordpress.com/2008/11/dewey_c reative_dem.pdf .

Mihaela C, V. Boghian, I 2014. Teaching the Relevance of Game Based Learning to Preschool and Primary Teachers. Procedia_ Social and Behavioral Sciences 142 (2014)640-646. 